\title{
Alternative programs to presynchronize estrous cycles in dairy cattle before a timed artificial insemination program ${ }^{1}$
}

\author{
J. S. Stevenson ${ }^{2}$ \\ Department of Animal Sciences and Industry, Kansas State University, Manhattan 66506-0201
}

\begin{abstract}
The objective was to test potential presynchronization programs applied to cows before a timed artificial insemination (TAI) program to increase the percentage of cows ovulating in response to both GnRH injections of a TAI program and having a functional corpus luteum before the first GnRH injection of the TAI program. At calving, cows were blocked by lactation (1 vs. $2+$ ) and assigned randomly to receive 1 of 5 presynchronization treatments. Two variants of the standard Presynch program were tested in which 2 injections of $\mathrm{PGF}_{2 \alpha}$ were administered $14 \mathrm{~d}$ apart with either 14 $\mathrm{d}$ (Pre14; $\mathrm{n}=122), 12 \mathrm{~d}$ (Pre12; $\mathrm{n}=123)$, or $10 \mathrm{~d}$ (Pre10; $\mathrm{n}=151$ ) intervening before a TAI program was initiated. Two other presynchronization programs consisted of administering a progesterone-releasing controlled internal drug release (CIDR) insert for $7 \mathrm{~d}$ plus $\mathrm{PGF}_{2 \alpha}$ administration at insert removal. Insert removal occurred either $10 \mathrm{~d}$ (CIDR10; $\mathrm{n}=157$ ) or $3 \mathrm{~d}$ (CIDR3; $\mathrm{n}=117$ ) before a TAI program was initiated. The TAI program was a standard Cosynch program [injection of GnRH $7 \mathrm{~d}$ before (GnRH-1) and $72 \mathrm{~h}$ after (GnRH2) $\mathrm{PGF}_{2 \alpha}$ with TAI administered $72 \mathrm{~h}$ after $\mathrm{PGF}_{2 \alpha}$ ). Cosynch served as the control $(\mathrm{n}=157)$, and cows were assumed to be starting this program at random stages of the estrous cycle. From a subset of cows per treatment (ranging from 49 to 51 cows each), blood samples were collected from coccygeal vessels by using evacuated tubes at $\mathrm{d}-28,-14,0$ (onset of TAI program), 7 , 9,14 , and 21. Ovarian scans were conducted on d 0,7 , 9,14 , and 21 by transrectal ultrasonography. Diameters of follicles and corpus luteum were measured at each exam, and ovulation was determined on d 7 (response to GnRH-1 on d 0) and d 14 (response to GnRH-2 on d 10). Ovulatory incidence after GnRH-1 (47.1 to
\end{abstract}

\footnotetext{
Received April 26, 2010

Accepted September 20, 2010.

${ }^{1}$ Contribution number 10-316-J from the Kansas Agricultural Experiment Station, Manhattan 66506.

${ }^{2}$ Corresponding author: jss@k-state.edu
}

$67.3 \%$ ) and GnRH-2 (78 to $90.2 \%$ ) varied but did not differ among treatments. Before GnRH-1, progesterone concentrations were less in the CIDR3 treatment than in all other treatments. Before GnRH-2, progesterone was greater in the CIDR3 treatment than in all other treatments. Luteal regression and synchronization rate (successful luteolysis and ovulation after GnRH-2) did not differ among treatments. Pregnancy rate per $\mathrm{AI}$ at 32 and $60 \mathrm{~d}$ post TAI was less in CIDR3 cows than in cows in all other treatments. None of the Presynch treatments improved key responses (ovulation, luteolysis, and synchronization rate) known to improve fertility compared with a standard Cosynch program without presynchronization.

Key words: luteolysis, ovulation, timed AI

\section{INTRODUCTION}

When timed artificial insemination (TAI) programs were first attempted using Ovsynch [injection of $\mathrm{GnRH}$ $7 \mathrm{~d}$ before $(\mathbf{G n R H}-\mathbf{1})$ and $48 \mathrm{~h}(\mathbf{G n R H}-2)$ after $\mathrm{PGF}_{2 \alpha}$ with TAI administered 16 to $20 \mathrm{~h}$ after GnRH-2], lactating dairy cows treated with this program between d 5 and 12 of the estrous cycle had a pregnancy rate per AI (PR/AI) advantage relative to cows treated at other stages of the cycle (Vasconcelos et al., 1999). On the basis of the hypothesis that fertility after a TAI program was related to the stage of the estrous cycle, presynchronization of estrous cycles was attempted before the Ovsynch program by using 2 injections of $\mathrm{PGF}_{2 \alpha}$ administered $14 \mathrm{~d}$ apart (Presynch). The second Presynch injection given $12 \mathrm{~d}$ before the onset of the TAI program (Moreira et al., 2001) resulted in a larger proportion of cows between d 5 and 12 of the estrous cycle at the onset of the TAI program. These cows had a significant improvement in PR/AI compared with cows at random stages of the estrous cycle (Moreira et al., 2001) and cows in subsequent experiments in which estrous cycles were presynchronized after administration of 1 (Cartmill et al., 2001) or 2 presynchronizing injections of $\mathrm{PGF}_{2 \alpha}$ (El-Zarkouny et al., 2004; Navanukraw 
et al., 2004; Galvão et al., 2007). In the latter 2 studies, the interval from the second Presynch injection to onset of the TAI program was $14 \mathrm{~d}$ rather than $12 \mathrm{~d}$. In other experiments, however, single injections of $\mathrm{PGF}_{2 \alpha}$ given 3 d (Meyer et al., 2007), 10 d (LeBlanc and Leslie, 2003), or 12 d (Cartmill et al., 2001) before initiating a TAI program failed to improve PR/AI.

In subsequent experiments initiated after the present study, presynchronization of estrous cycles accomplished by injecting $\mathrm{PGF}_{2 \alpha}$ and GnRH (Bello et al., 2006) or by using an Ovsynch program before the TAI Ovsynch program (Souza et al., 2008) resulted in improved PR/AI. Applying an intravaginal progesterone insert (Chebel et al., 2006; Bicalho et al., 2007; Rutigliano et al., 2008) at various intervals before initiating a TAI program to appropriately stage the estrous cycle failed to improve PR/AI compared with a standard Presynch program but may have benefitted some anovulatory cows (Chebel et al., 2006) by inducing estrous cycles without affecting fertility (Cerri et al., 2009).

Improved PR/AI in TAI programs is associated with (1) greater ovulation response to the first $\mathrm{GnRH}$ injection of Ovsynch (Vasconcelos et al., 1999; Bello et al., 2006), (2) more cows having a functional corpus luteum (CL) at the first GnRH injection (Galvão and Santos, 2010), (3) greater ovulatory response to the first GnRH injection increasing ovulatory response to the second GnRH injection (Rutigliano et al., 2008), and (4) greater ovulation response after TAI (Galvão and Santos, 2010). Researchers concluded that presynchronization with 2 injections of $\mathrm{PGF}_{2 \alpha}$ (Presynch) and initiation of the Ovsynch $14 \mathrm{~d}$ later decreased ovulatory responses to the first and second GnRH injections. Therefore, a 14-d interval between presynchronization and the first GnRH injection might not be adequate to optimize fertility in dairy cows (Galvão and Santos, 2010).

The objective was to test potential presynchronization programs administered before a TAI program that might improve the percentage of cows having a functional CL, having elevated progesterone concentrations, and successfully ovulating in response to both GnRH injections of a TAI Ovsynch-like program. The hypothesis was that reducing the interval from the second Presynch $\mathrm{PGF}_{2 \alpha}$ injection from 14 to 10 $\mathrm{d}$ would increase the proportion of cows ovulating in response to GnRH-1. Further, applying progesterone via a controlled internal drug release (CIDR) insert for $7 \mathrm{~d}$ and removing the CIDR $10 \mathrm{~d}$ before GnRH-1 might have favorable effects on anovulatory or anestrous cows and enhance responses to a TAI program. In contrast, applying a CIDR for $7 \mathrm{~d}$ and removing it $3 \mathrm{~d}$ before initiation of a TAI program would produce unfavorable effects on responses to ovulation synchronization, including fertility.

\section{MATERIALS AND METHODS}

\section{Experimental Cows}

The current studies were approved by the Kansas State University Institutional Animal Care and Use Committee. Lactating Holstein cows were enrolled between October 2004 and January 2009 at the Kansas State University Dairy Teaching and Research Center. Cows were housed in covered freestalls and fed twice or thrice (summer) daily a TMR calculated to meet nutrient requirements for lactating dairy cows producing $50 \mathrm{~kg}$ of $3.5 \%$ milk (NRC, 2001). The diet consisted of alfalfa hay, corn silage, soybean meal, whole cotton seed, corn or milo grain, sweet bran, vitamins, and minerals. Cows were milked twice daily and treated with recombinant bST according to label directions.

\section{Experimental Design}

At calving, cows were blocked by lactation number (1 vs. $2+$ ) and assigned randomly to receive 1 of 5 presynchronization treatments (Figure 1). Two permutations of the standard Presynch program were tested in which 2 injections of $\mathrm{PGF}_{2 \alpha}$ ( $5 \mathrm{~mL}$ of Lutalyse Sterile Solution; Pfizer Animal Health, New York, NY) were administered $14 \mathrm{~d}$ apart with either $14 \mathrm{~d}$ (Pre14; $\mathrm{n}=$ 122), 12 d (Pre12; n = 123), or 10 d (Pre10; $n=151)$ intervening before a TAI program was initiated. The rationale for decreasing the number of intervening days between the second $\mathrm{PGF}_{2 \alpha}$ injection and the onset of the TAI program was to place more cows at a time in their cycle when the first-wave dominant follicle would be likely to ovulate in response to $\mathrm{GnRH}$-induced LH release (Vasconcelos et al., 1999; Moreira et al., 2000). Figure 1 shows the predicted days of the estrous cycle for these treatments. Two other presynchronization programs consisted of administering a progesteronereleasing Eazi-Breed CIDR cattle insert (Pfizer Animal Health) containing $1.38 \mathrm{~g}$ of progesterone for $7 \mathrm{~d}$ plus $\mathrm{PGF}_{2 \alpha}$ administration at insert removal. Insert removal occurred either $10 \mathrm{~d}($ CIDR10; $\mathrm{n}=157)$ or $3 \mathrm{~d}$ (CIDR3; $\mathrm{n}=117$ ) before a TAI program was initiated. The TAI program was a standard Cosynch program [100 $\mu \mathrm{g}$ of GnRH $7 \mathrm{~d}$ before (GnRH-1) and $72 \mathrm{~h}$ after (GnRH-2) $25 \mathrm{mg}$ of $\mathrm{PGF}_{2 \alpha}$ with TAI administered 72 $\mathrm{h}$ after $\left.\mathrm{PGF}_{2 \alpha}\right]$. Cows administered Cosynch served as the control $(\mathrm{n}=157)$, and cows were assumed to be starting this program at random stages of the estrous cycle. The CIDR3 treatment was a negative control; the hypothesis was that these cows would be at a disadvantage by starting the TAI program near estrus in a low-progesterone environment. Body condition scores were assigned on median $\mathrm{d}-28$. The GnRH products 


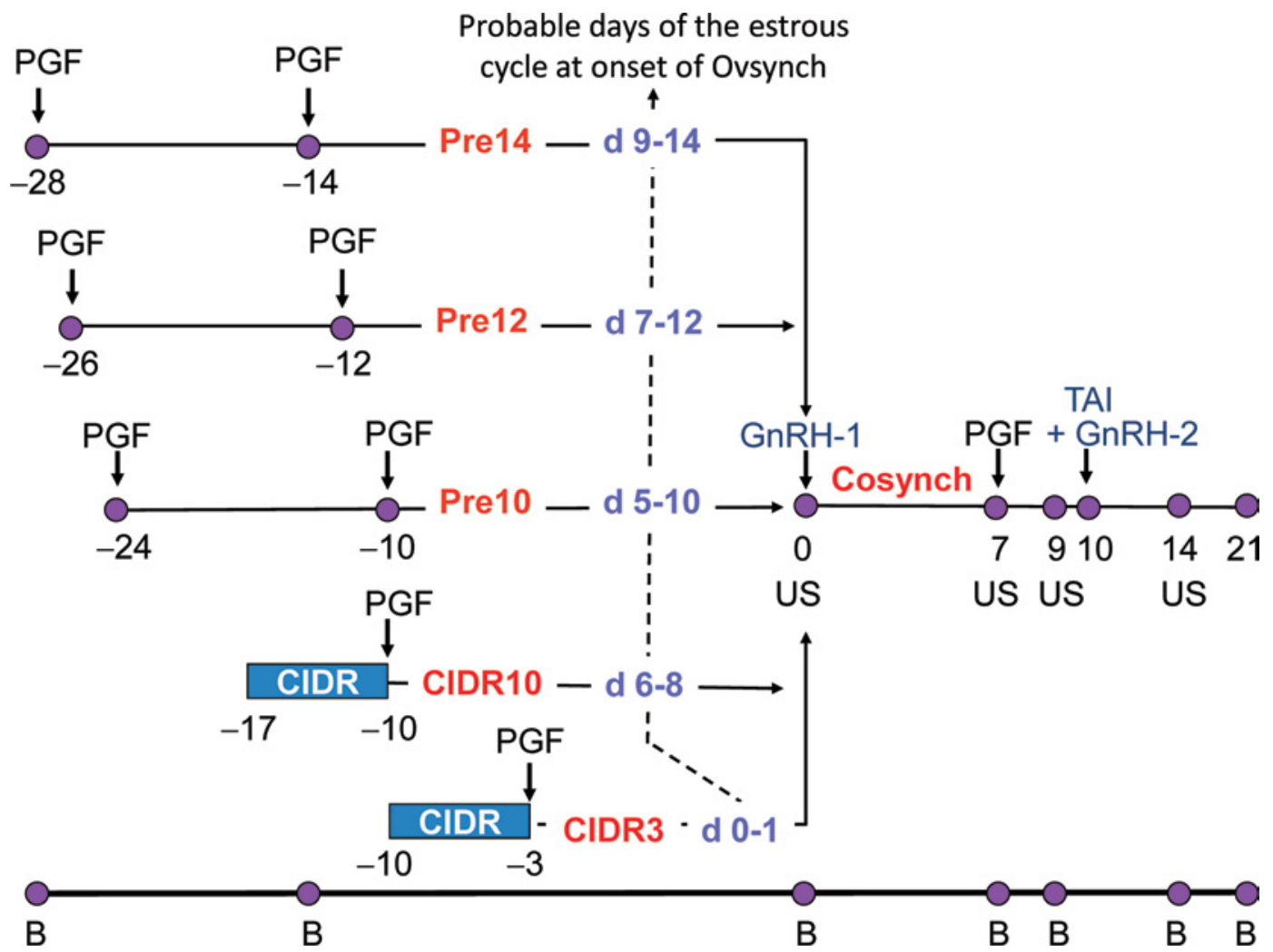

Figure 1. Five treatments designed to presynchronize the estrous cycle before the onset of a timed AI program (Cosynch; control) are illustrated. Injections of $\mathrm{PGF}_{2 \alpha}$ were administered $14 \mathrm{~d}$ apart, with the second injection administered $14 \mathrm{~d}$ (Pre14), $12 \mathrm{~d}$ (Pre12), or 10 d (Pre10) before the onset of the Cosynch program. A controlled internal drug release (CIDR) insert containing $1.38 \mathrm{~g}$ of progesterone was inserted for 7 $\mathrm{d}$ and removed either $10 \mathrm{~d}$ (CIDR10) or $3 \mathrm{~d}$ (CIDR3; negative control) before the onset of the Cosynch program. Blood samples were collected and transrectal ovarian ultrasonography was performed in a subset of 49 to 51 cows per treatment as indicated. Probable days of the estrous cycle at the onset of the Cosynch program (random stages of estrous cycle) are illustrated. Abbreviations: $\mathrm{B}=\mathrm{blood}$ samples; $\mathrm{GnRH}=100 \mu \mathrm{g}$ of gonadotropin-releasing hormone; $\mathrm{PGF}=25 \mathrm{mg}$ of $\mathrm{PGF}_{2 \alpha}$; TAI = timed $\mathrm{AI}$ at $72 \mathrm{~h}$ after $\mathrm{PGF}_{2 \alpha}$; US = ultrasonography. Color version available in the online PDF.

used were gonadorelin diacetate tetrahydrates $(2 \mathrm{~mL}$ of Cystorelin, Merial Ltd., Duluth, GA; or $2 \mathrm{~mL}$ of OvaCyst, IVX Animal Health, St. Joseph, MO).

A new breeding cluster of cows was initiated every 2 wk at a median of 38 DIM, when cows were scored for body condition (Ferguson et al., 1994). Treatments had staggered starting times within cluster, so all treated cows within cluster were inseminated on the same day (Figure 1). Five technicians performed all AI, with 1 technician performing $84 \%$ of all AI. Multiple sires were used. Pregnancy diagnosis via transrectal ultrasonography (5.0 MHz linear-array transducer, Aloka 500V, Corometrics Medical Systems Inc., Wallingford, CT) occurred 32 and $60 \mathrm{~d}$ after TAI. A positive pregnancy outcome required the presence of anechoic uterine fluid and a large CL or anechoic uterine fluid and presence of a viable embryo.

To produce sufficient replication for assessing PR/AI [12 percentage point increase (El-Zarkouny et al., 2004) with $\alpha=0.10$ and $\beta=0.10$ for PR/AI ranging from 30 to $40 \%$ required 147 to 154 cows per treatment], more cows were assigned randomly to the 2 uniquely different treatments not previously tested in the literature (Pre10 and CIDR10) plus the Cosynch control. Therefore, numbers of cows per treatment for examining PR/ AI were greater in the former 2 treatments and the Cosynch control (n ranged from 151 to 157 ) than in the latter 3 treatments (n ranged from 117 to 123).

\section{Blood Sampling and Ultrasonography}

From a subset of cows per treatment (ranging from 49 to 51 cows each), blood samples were collected from coccygeal vessels by using evacuated tubes at $\mathrm{d}-28$, $-14,0$ (onset of TAI program), 7, 9, 14, and 21 (Figure $1)$. Samples were stored on ice and transported to the laboratory for storage at $5^{\circ} \mathrm{C}$ until serum was harvested by centrifugation $(1,200 \times g)$. Serum samples were stored at $-15^{\circ} \mathrm{C}$ until they were assayed for progesterone concentration by radioimmunoassay (Skaggs et al., 
1986). Inter- and intraassay coefficients of variation for 8 assays were 10.9 and $8.2 \%$, respectively, for a pooled serum sample that averaged $4.55 \pm 0.11 \mathrm{ng} / \mathrm{mL}(\mathrm{n}=$ 41). Concentrations of estradiol-17 $\beta$ were measured by RIA (Perry et al., 1991) in blood serum collected on d 9 from the same subset of cows with some modifications. Blood serum before assay was extracted by 10 volumes of methyl T-butyl ether (HPLC grade, Fisher Scientific, St. Louis, MO). The radioligand $\left({ }^{125}\right.$ I-labeled $17 \beta$-estradiol; 1,500 to $2,000 \mu \mathrm{Ci} / \mu \mathrm{g})$ was purchased from MP Biomedicals LLC (Solon, OH). Recovery of added mass $(1,2,4,8$, and $16 \mathrm{pg})$ added in quadruplicate to 3 different bovine serum samples $(300 \mu \mathrm{L})$ averaged $109 \%$. Parallelism was demonstrated by assaying 150-, 200-, 250-, and 300- $\mu \mathrm{L}$ aliquots of bovine serum in quadruplicate and recovering $102 \%$ of that assayed in the $300-\mu \mathrm{L}$ sample of bovine serum. Inter- and intraassay coefficients of variation for 2 assays were 6.6 and $5.5 \%$, respectively, for a pooled serum sample that averaged $6.33 \pm 0.14 \mathrm{pg} / \mathrm{mL}(\mathrm{n}=8)$.

\section{Measurements}

On the basis of serum progesterone concentrations on $\mathrm{d}-28$ and -14 , cows were classified as anovulatory when progesterone was $<1 \mathrm{ng} / \mathrm{mL}$ on both days; otherwise they were classified as having ovulated previously (cycling). Because cows in the CIDR10 treatment had been exposed to a CIDR in situ for $3 \mathrm{~d}$ on $\mathrm{d}-14$, the concentration on $\mathrm{d}-14$ must have exceeded $2 \mathrm{ng} / \mathrm{mL}$ for the cow to be classified as cycling when the concentration was $<1 \mathrm{ng} / \mathrm{mL}$ on $\mathrm{d}-28$. Stevenson et al. (2006) previously reported that in lactating dairy cows treated with a CIDR insert and having a functional CL at insert removal, the decrease in progesterone concentration was only $0.5 \pm 0.1 \mathrm{ng} / \mathrm{mL}$ between the time of insert removal and a $\mathrm{PGF}_{2 \alpha}$ injection given 1 to 2 $\mathrm{h}$ later. These small differences in progesterone concentration indicated that the progesterone contribution of the CIDR insert to peripheral serum progesterone concentrations was small in the presence of a functional CL. Recently, Cerri et al. (2009) demonstrated that progesterone concentrations in the blood serum of lactating cows treated with a CIDR for $7 \mathrm{~d}$ beginning 2 $\mathrm{d}$ after $\mathrm{PGF}_{2 \alpha}$-induced luteolysis were mostly subluteal $(<1 \mathrm{ng} / \mathrm{mL})$ after $\mathrm{d} 2$ of administration.

Induced ovulation was defined to occur in previously anovulatory cows in response to treatment when progesterone exceeded $1 \mathrm{ng} / \mathrm{mL}$ on d 0 (onset of TAI program). The percentage of cows with elevated $(\geq 1 \mathrm{ng} /$ $\mathrm{mL}$ ) progesterone on $\mathrm{d} 0,7,14$, and 21 after initiation of Cosynch or those with reduced $(<1 \mathrm{ng} / \mathrm{mL})$ concentrations on d $9\left(2 \mathrm{~d}\right.$ post $\left.\mathrm{PGF}_{2 \alpha}\right)$ were calculated.
The percentage of cows with luteolysis was based on those with an observed CL and progesterone $\geq 1 \mathrm{ng} / \mathrm{mL}$ before $\mathrm{PGF}_{2 \alpha}$ injection and low progesterone concentrations $48 \mathrm{~h}$ later.

Ovarian scans were carried out on d $0,7,9$, and 14 by transrectal ultrasonography (Figure 1). Diameter of follicles and CL (and their fluid-filled cavity) were measured at each exam. Ovulation response to GnRH-1 on d 0 and GnRH-2 on d 0 was determined on d 7 and 14, respectively, when a newly appearing CL was found at the site of a previously recorded follicle. Number of CL was counted at each exam, and their volume was calculated $\left[4 / 3 \times \mathrm{R}^{3} \times \pi\right.$, where $\mathrm{W}=$ largest width and $\mathrm{H}=$ largest height of the structure; $\mathrm{R}=$ radius; $(\mathrm{W} / 2+\mathrm{H} / 2) / 2$, and $\pi=3.14159]$. When a CL contained a fluid-filled cavity, the volume of the cavity was subtracted from the calculated CL volume. A successful synchronization occurred (synchronization rate) when luteolysis was achieved by $48 \mathrm{~h}$ after $\mathrm{PGF}_{2 \alpha}$ injection and a new CL was found $5 \mathrm{~d}$ after TAI at the same location as the largest follicle identified at $48 \mathrm{~h}$ after $\mathrm{PGF}_{2 \alpha}$.

\section{Statistical Analyses}

Various ovarian binomial characteristics and responses to hormonal injections $\left(\mathrm{GnRH}\right.$ and $\left.\mathrm{PGF}_{2 \alpha}\right)$ were analyzed by logistic regression (procedure LOGISTIC, SAS Inst. Inc., Cary, NC). These included percentage of cows with elevated $(\geq 1 \mathrm{ng} / \mathrm{mL})$ or reduced $(<1 \mathrm{ng} /$ $\mathrm{mL}$ ) progesterone concentrations, ovulation response to GnRH-1 and GnRH-2, and number of CL. The initial model included treatment $(\mathrm{n}=6)$, lactation number $(1$ vs. 2+), season of year (hot = May to August; moderate $=$ March, April, September, and October; cold = November to February), DIM at TAI $(>76$ or $\leq 76$ $\mathrm{d}$; median $=76)$, treatment $\times$ lactation number interaction, and BCS at the onset of the Pre14 treatment $(>2.25$ or $\leq 2.25$; median $=2.25)$. The final model produced by backward stepwise selection of independent variables entered or retained in the model was based on a Wald statistic $(P<0.10)$.

Continuous variables and responses to hormonal injections (progesterone and estradiol concentrations, cavity-corrected CL volume, and follicle diameter) were analyzed by using a general linear model (procedure GLM, SAS Inst. Inc., Cary, NC). The basic model for determining volume of CL before each hormonal injection included treatment $(\mathrm{n}=6)$, lactation number $(1$ vs. $2+)$, their interaction, $\mathrm{BCS}(>2.25$ or $\leq 2.25$; median $=2.25)$, and DIM $(>76$ or $\leq 76 ;$ median $=76$ d). Models to analyze the diameter of the largest follicle before both GnRH injections included treatment $(\mathrm{n}=$ 
6 ), cycling status ( 0 vs. 1 ), lactation number ( 1 vs. $2+$ ), BCS $(>2.25$ or $\leq 2.25$; median $=2.25)$, DIM $(>76$ or $\leq 76$; median $=76 \mathrm{~d})$, ovulation response ( 0 vs. 1$)$, and the interaction of treatment and ovulation response. Simple Pearson correlation coefficients among CL characteristics and progesterone concentrations were determined by procedure CORR (SAS Inst. Inc.).

Pregnancy rates per AI at d 32 and 60 were analyzed as described previously for other binomial variables. The initial model included treatment $(\mathrm{n}=6)$, cyclicity $(0$ vs. 1$)$, lactation number $(1$ vs. $2+)$, season $(\mathrm{n}=3)$, BCS $(>2.25$ or $\leq 2.25$; median $=2.25)$, and DIM $(>76$ or $\leq 76$; median $=76 \mathrm{~d}$ ) at TAI. The final model produced by backward stepwise selection of independent variables entered or retained in the model based on a Wald statistic $(P<0.10)$ included treatment and cyclicity for both times of pregnancy diagnosis.

Relationships of various traits to the possible success of ovulation after both $\mathrm{GnRH}$ injections were modeled by using logistic regression (procedure LOGISTIC, SAS Inst. Inc.). All traits were regressed, and adjusted odds ratios were calculated. The final model produced by backward stepwise selection of independent variables entered or retained in the model was based on a Wald statistic $(P<0.10)$.

Estimates of pretreatment and posttreatment ovarian cyclicity assessed by serum progesterone concentrations described previously were analyzed by chi-squared frequency (procedure FREQ, SAS Inst. Inc.) by using the Cochran-Mantel-Haenszel statistics. Various comparisons in 34 anovulatory cows [reduced $(<1 \mathrm{ng} /$ $\mathrm{mL}$ ) progesterone concentrations on $\mathrm{d}-28,-14$, and 0 and no ultrasound-detected CL on d 0] were made in cows subsequently treated with a CIDR or not before Cosynch. The models included progesterone treatment $(0$ vs. 1$)$ and lactation number (1 vs. $2+$ ). Binomial and continuous variable models were applied as described previously for other like independent variables.

\section{RESULTS}

\section{Ovarian Responses to $\mathrm{GnRH}-1$}

Responses to GnRH-1 are summarized in Table 1. As anticipated from the treatment design, progesterone concentrations were lesser $(P<0.05)$ in the CIDR3 treatment than in all other treatments. Progesterone concentrations were less $(P<0.05)$ in Pre10 cows than in Pre12 and Pre14 cows, which by experimental design, were likely earlier in their estrous cycles at the onset of the timed AI program (Figure 1). Cows with BCS $\leq 2.25$ had lesser $(P<0.05)$ progesterone concentrations than did cows in greater $(>2.25)$ body condition $(2.5 \pm 0.2$ vs. $3.3 \pm 0.3 \mathrm{ng} / \mathrm{mL}$, respectively).
The proportion of cows with at least 1 CL at the time of GnRH-1 mirrored the percentages of cows with high progesterone with 1 exception (Table 1). Only $12 \%$ of CIDR3 cows had elevated $(\geq 1 \mathrm{ng} / \mathrm{mL})$ progesterone at $\mathrm{GnRH}-1$, but $43 \%$ had at least $1 \mathrm{CL}$ that was regressing (data not shown). Proportions of cows with progesterone $\geq 1 \mathrm{ng} / \mathrm{mL}$ at $\mathrm{GnRH}-1$ that ovulated were 56.8, 68.6, 74.3, 65.8, 33.3, and 64.5\% for Pre14, Pre12, Pre10, CIDR10, CIDR3, and Cosynch, respectively.

A greater $(P<0.05)$ proportion of cows with DIM greater than the median of 76 at TAI had elevated progesterone at GnRH-1 compared with cows with less than the median DIM at TAI (67.8 vs. $49.6 \%)$. The number of CL present at GnRH-1 and the total CL volume at the time of GnRH-1 were less $(P<0.05)$ in CIDR3 cows than in cows in all other treatments (Table 1). Mean diameters of the largest (putative dominant) follicle varied slightly among treatments (12.7 to 14.1 $\mathrm{mm}$ ). Although ovulatory response to $\mathrm{GnRH}-1$ looked numerically less in CIDR3 cows (43.1\%), it did not differ $(P=0.219)$ from that in all other treatments $(>60 \%$; Table 2$)$.

Relationships of all traits to the success of ovulation after GnRH-1 were modeled. In the full model, only follicle diameter before GnRH-1 was associated $(P=$ $0.015)$ with ovulation (Table 3 ). After backward stepwise selection, progesterone concentrations and largest follicle diameter were associated with ovulation after GnRH-1. Cows with follicle diameters $>14 \mathrm{~mm}$ were 1.8 times more $(P=0.019 ; 95 \% \mathrm{CI}=1.10$ to 2.89$)$ likely to ovulate than cows with follicles $\leq 14 \mathrm{~mm}$. Further, cows with progesterone concentrations $\geq 1 \mathrm{ng} / \mathrm{mL}$ were 1.7 times more $(P=0.02 ; 95 \% \mathrm{CI}=1.08$ to 2.81$)$ likely to ovulate than cows with progesterone concentrations $<1$ ng/mL before GnRH-1.

\section{Ovarian Characteristics at Time of $P G F_{2 a}$}

Various ovarian characteristics at the time of $\mathrm{PGF}_{2 \alpha}$ injection are summarized in Table 1. Progesterone concentrations were greater $(P<0.05)$ in Pre14, Pre10, and CIDR10 cows than in Pre12, CIDR3, and Cosynch control cows. Cows in the CIDR3 treatment had fewer $(P<0.05)$ CL per cow than cows in all other treatments, and cows in the Cosynch control had an intermediate number of CL (Table 1). The volume of luteal tissue (CL) that formed after ovulation in response to GnRH-1 did not differ among treatments and was not affected by lactation number. In contrast, original CL volume before $\mathrm{PGF}_{2 \alpha}$ injection and total $\mathrm{CL}$ volume (original CL plus new CL induced by GnRH-1) varied among treatments. Original CL volumes were greater $(P<0.05)$ in Pre14, Pre10, and CIDR10 treatments than in the Cosynch control (Table 1). Further, total 
Table 1. Ovarian characteristics and serum progesterone concentrations at the time of or in response to the first (GnRH-1) and second (GnRH2) $\mathrm{GnRH}$ injections and $\mathrm{PGF}_{2 \alpha}$ injection of a timed $\mathrm{AI}$ ovulation synchronization program (Cosynch)

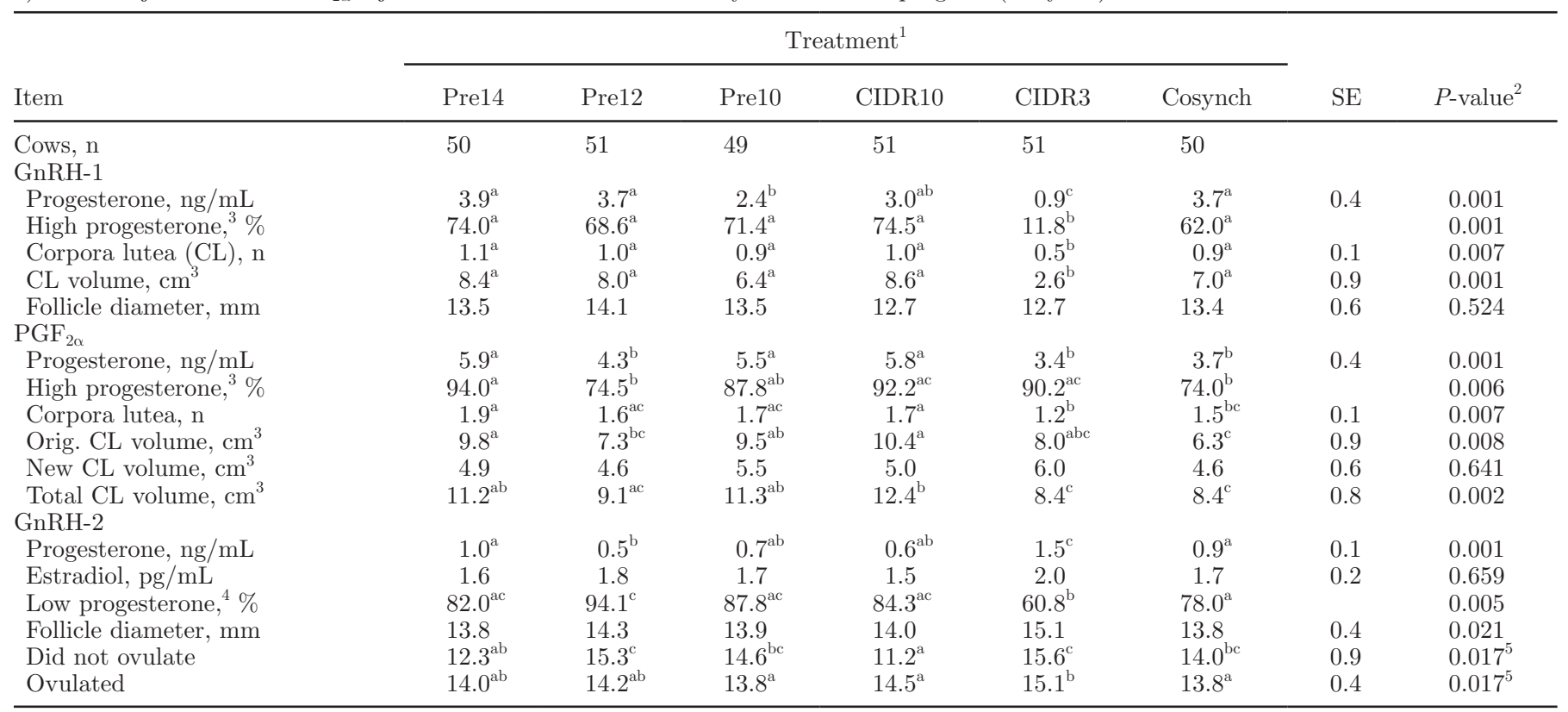

${ }^{\mathrm{a}-\mathrm{c}}$ Means within a row with different superscripts differ $(P \leq 0.05)$.

${ }^{1}$ Injections of $\mathrm{PGF}_{2 \alpha}$ were administered $14 \mathrm{~d}$ apart, with the second injection administered $14 \mathrm{~d}$ (Pre14), $12 \mathrm{~d}$ (Pre12), or $10 \mathrm{~d}$ (Pre10) before the onset of the Cosynch program (see Figure 1). A progesterone-releasing controlled internal drug release (CIDR) insert was inserted for $7 \mathrm{~d}$ and removed either $10 \mathrm{~d}$ (CIDR10) or $3 \mathrm{~d}$ (CIDR3) before the onset of the Cosynch program.

${ }^{2}$ Treatment $P$-value.

${ }^{3}$ Percentage of cows with progesterone $\geq 1 \mathrm{ng} / \mathrm{mL}$.

${ }^{4}$ Percentage of cows with progesterone $<1 \mathrm{ng} / \mathrm{mL}$.

${ }^{5}$ Treatment $\times$ ovulation response interaction.

CL volume was greater $(P<0.05)$ in Pre14, Pre10, and CIDR10 treatments than in the CIDR3 treatment and Cosynch control. Volumes of the original CL $(7.7 \pm 0.6$ vs. $\left.9.4 \pm 0.5 \mathrm{~cm}^{3}\right)$ and total CL $(9.4 \pm 0.5$ vs. $10.9 \pm 0.5$ $\left.\mathrm{cm}^{3}\right)$ were consistently less $(P<0.05)$ in first-lactation cows than in older cows. Progesterone concentration did not differ between first-lactation and older cows (4.96 \pm 41 vs. $4.55 \pm 0.28 \mathrm{ng} / \mathrm{mL}$, respectively).

Table 2. Ovulation responses to the first and second GnRH injections, luteolysis, and synchronization rate of treated cows during the timed AI ovulation synchronization program (Cosynch) after various presynchronization treatments

\begin{tabular}{|c|c|c|c|c|c|}
\hline \multirow[b]{2}{*}{ Treatment $^{1}$} & \multirow[b]{2}{*}{$\mathrm{n}$} & \multicolumn{2}{|c|}{ Ovulation $^{2}$} & \multirow[b]{2}{*}{$\begin{array}{c}\text { Luteolysis, }^{3} \\
\%\end{array}$} & \multirow[b]{2}{*}{$\begin{array}{c}\text { Synchronization } \\
\text { rate, }{ }^{4} \%\end{array}$} \\
\hline & & $\underset{\%}{\operatorname{GnRH}}-1$, & $\underset{\%}{\mathrm{GnRH}-2,}$ & & \\
\hline Pre14 & 50 & 62.0 & 86.0 & 93.9 & 86.0 \\
\hline Pre12 & 51 & 60.8 & 88.2 & 100 & 88.2 \\
\hline Pre10 & 49 & 65.3 & 79.6 & 95.7 & 79.6 \\
\hline CIDR10 & 51 & 64.7 & 86.3 & 100 & 86.3 \\
\hline CIDR3 & 51 & 43.1 & 90.2 & 83.0 & 86.3 \\
\hline Cosynch & 50 & 62.0 & 78.0 & 93.0 & 76.0 \\
\hline
\end{tabular}

${ }^{1}$ Injections of $\mathrm{PGF}_{2 \alpha}$ were administered $14 \mathrm{~d}$ apart, with the second injection administered $14 \mathrm{~d}$ (Pre14), 12 $\mathrm{d}$ (Pre12), or $10 \mathrm{~d}$ (Pre10) before the onset of the Cosynch program (see Figure 1). A progesterone-releasing controlled internal drug release (CIDR) insert was inserted for $7 \mathrm{~d}$ and removed either $10 \mathrm{~d}$ (CIDR10) or $3 \mathrm{~d}$ (CIDR3) before the onset of the Cosynch program.

${ }^{2}$ Proportion of cows ovulating after the first or second GnRH injection of the Cosynch program.

${ }^{3}$ Proportion of cows having luteal regression (decrease in progesterone concentrations from $\geq 1 \mathrm{ng} / \mathrm{mL}$ before $\mathrm{PGF}_{2 \alpha}$ to $<1 \mathrm{ng} / \mathrm{mL} 48 \mathrm{~h}$ later $)$.

${ }^{4}$ Synchronization rate (proportion of cows having luteal regression and ovulating after GnRH-2). 
Table 3. Relationships of traits to ovulation success after the first GnRH injection (GnRH-1) of Cosynch

\begin{tabular}{|c|c|c|c|c|c|c|c|}
\hline \multirow[b]{2}{*}{ Trait } & \multirow[b]{2}{*}{ Level } & \multirow[b]{2}{*}{$\mathrm{n}$} & \multirow{2}{*}{$\begin{array}{c}\text { Ovulation, } \\
\%\end{array}$} & \multirow[b]{2}{*}{$P$-value } & \multirow[b]{2}{*}{$\mathrm{AOR}^{1}$} & \multicolumn{2}{|c|}{$95 \% \mathrm{CI}$} \\
\hline & & & & & & Lower & Upper \\
\hline \multirow[t]{6}{*}{ Treatment $^{2}$} & Pre14 & 50 & 62.0 & & 1.12 & 0.49 & 2.56 \\
\hline & Pre12 & 51 & 60.8 & & 1.17 & 0.51 & 2.71 \\
\hline & Pre10 & 49 & 65.3 & & 0.93 & 0.40 & 2.16 \\
\hline & CIDR10 & 51 & 64.7 & & 0.91 & 0.39 & 2.12 \\
\hline & CIDR3 & 51 & 43.1 & & 1.91 & 0.81 & 4.53 \\
\hline & Cosynch & 50 & 62.0 & 0.62 & & & \\
\hline \multirow[t]{2}{*}{ Corpus luteum ${ }^{3}$} & Absent & 89 & 53.9 & & & & \\
\hline & Present & 213 & 62.0 & 0.76 & 0.89 & 0.43 & 1.86 \\
\hline \multirow{2}{*}{ Progesterone,${ }^{3} \mathrm{ng} / \mathrm{mL}$} & $<1$ & 120 & 51.7 & & & & \\
\hline & $\geq 1$ & 182 & 64.8 & 0.39 & 1.39 & 0.66 & 2.92 \\
\hline \multirow{2}{*}{ Follicle diameter, ${ }^{3} \mathrm{~mm}$} & $\leq 14$ & 178 & 54.5 & & & & \\
\hline & $>14$ & 123 & 67.5 & 0.02 & 1.88 & 1.13 & 3.11 \\
\hline \multirow[t]{2}{*}{ BCS } & $\leq 2.25$ & 194 & 59.8 & & & & \\
\hline & $>2.25$ & 108 & 59.3 & 0.93 & 0.98 & 0.57 & 1.66 \\
\hline \multirow[t]{2}{*}{ DIM } & $\leq 78$ & 158 & 58.9 & & & & \\
\hline & $>78$ & 144 & 60.4 & 0.74 & 0.92 & 0.56 & 1.51 \\
\hline \multirow[t]{2}{*}{ Cyclicity $^{4}$} & No & 40 & 50.0 & & & & \\
\hline & Yes & 262 & 61.1 & 0.47 & 1.36 & 0.59 & 3.14 \\
\hline \multirow[t]{2}{*}{ Lactation number } & 1 & 127 & 59.1 & & & & \\
\hline & $>1$ & 175 & 60.0 & 0.72 & 1.13 & 0.59 & 2.16 \\
\hline \multirow[t]{3}{*}{ Season } & Cold & 130 & 61.5 & & 1.01 & 0.55 & 1.85 \\
\hline & Moderate & 87 & 55.2 & & 1.42 & 0.75 & 2.71 \\
\hline & Hot & 85 & 61.2 & 0.44 & & & \\
\hline \multirow[t]{2}{*}{ Summit milk, ${ }^{5} \mathrm{~kg}$} & $\leq 50$ & 158 & 61.4 & & & & \\
\hline & $>50$ & 144 & 57.6 & 0.43 & 0.78 & 0.42 & 1.45 \\
\hline
\end{tabular}

${ }^{1}$ Adjusted odds ratio.

${ }^{2}$ Injections of $\mathrm{PGF}_{2 \alpha}$ were administered $14 \mathrm{~d}$ apart, with the second injection administered $14 \mathrm{~d}$ (Pre14), 12 $\mathrm{d}$ (Pre12), or $10 \mathrm{~d}$ (Pre10) before the onset of the Cosynch program (see Figure 1). A progesterone-releasing controlled internal drug release (CIDR) insert was inserted for $7 \mathrm{~d}$ and removed either $10 \mathrm{~d}$ (CIDR10) or $3 \mathrm{~d}$ (CIDR3) before the onset of the Cosynch program.

${ }^{3}$ Assessed just before GnRH injection.

${ }^{4}$ Cyclicity was based on serum progesterone concentrations 28,14 , and $0 \mathrm{~d}$ before the onset of a timed AI program.

${ }^{5}$ Average of the largest 2 of the first 3 test-day milk weights after calving.

\section{Ovarian Responses to GnRH-2}

At GnRH-2, progesterone concentrations averaged $<1 \mathrm{ng} / \mathrm{mL}$ in all treatments except CIDR3 (Table 1). Generally, more than $82 \%$ of cows had reduced $(<1 \mathrm{ng} /$ $\mathrm{mL}$ ) progesterone by $48 \mathrm{~h}$ after $\mathrm{PGF}_{2 \alpha}$ compared with only $61 \%$ of CIDR3 and $78 \%$ of Cosynch control cows.

Diameters of the largest follicle differed $(P=0.021)$ among treatments, but an interaction of treatment and ovulation status also was detected (Table 1). Follicles that ovulated after GnRH-2, regardless of treatment, were more uniform in diameter, ranging from an average of 13.8 to $15.1 \pm 0.4 \mathrm{~mm}$. In contrast, average diameters of follicles that did not ovulate were more variable in size (11.2 to $15.6 \pm 0.9 \mathrm{~mm})$. In both scenarios, follicles with the largest diameter were identified in the CIDR3 treatment. Estradiol concentrations did not differ among treatments (Table 1); however, estradiol was greater $(P<0.05)$ in cows that ovulated after GnRH-2 (1.67 \pm 0.2 vs. $1.28 \pm 0.2 \mathrm{pg} / \mathrm{mL})$ and in cows that were cycling before the onset of the Cosynch program $(1.74 \pm 0.1$ vs. $1.21 \pm 0.3 \mathrm{pg} / \mathrm{mL})$.

Ovulation response to $\mathrm{GnRH}-2$ ranged from 79.6 to $90.2 \%$ but did not differ $(P=0.357)$ among treatments (Table 2) despite clear differences in progesterone concentrations $48 \mathrm{~h}$ after $\mathrm{PGF}_{2 \alpha}$ (Table 1). Luteal regression ranged from 83 to $100 \%$ but did not differ $(P=$ 0.37) among treatments (Table 2). The CIDR3 cows, which started the Cosynch program in a low-progesterone environment, had the numerically lowest luteolytic success. Synchronization rate ranged from a low of $80 \%$ in Pre10 cows to a high of $88 \%$ in Pre 12 cows, but did not differ $(P=0.39)$ among treatments (Table 2$)$.

Relationships of all traits to the success of ovulation after GnRH-2 were modeled (Table 4). In the full model, only progesterone concentration at GnRH-2 was predictive $(P<0.001)$ of subsequent ovulation. After backward stepwise selection, the presence of $\mathrm{CL}$ at $\mathrm{PGF}_{2 \alpha}$ and progesterone concentrations before GnRH-2 was significantly associated with ovulation 
Table 4. Relationships of traits to ovulation success after the second GnRH injection (GnRH-2) of Cosynch

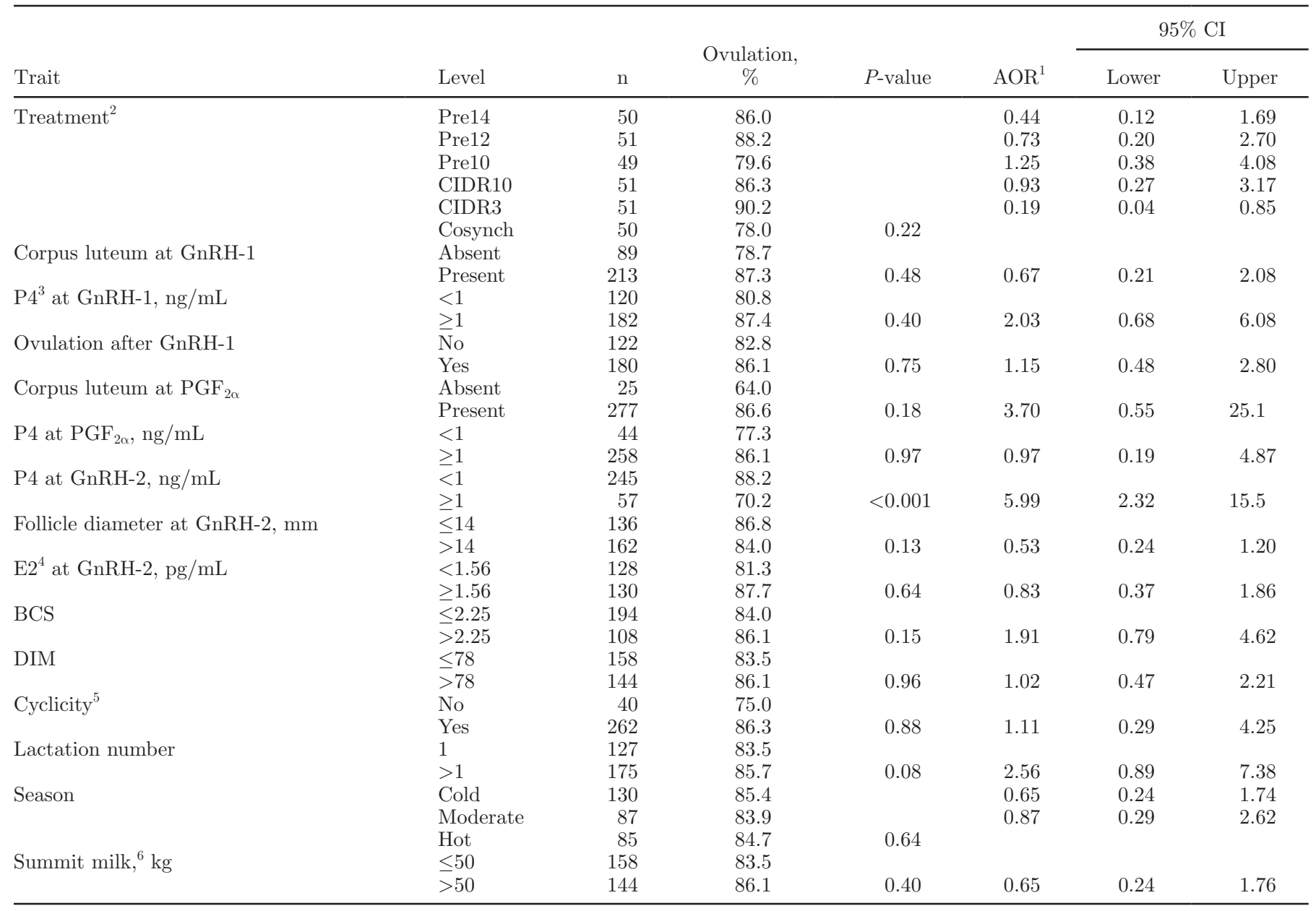

${ }^{1}$ Adjusted odds ratio.

${ }^{2}$ Injections of $\mathrm{PGF}_{2 \alpha}$ were administered $14 \mathrm{~d}$ apart, with the second injection administered $14 \mathrm{~d}$ (Pre14), $12 \mathrm{~d}$ (Pre12), or 10 d (Pre10) before the onset of the Cosynch program (see Figure 1). A progesterone-releasing controlled internal drug release (CIDR) insert was inserted for $7 \mathrm{~d}$ and removed either $10 \mathrm{~d}$ (CIDR10) or $3 \mathrm{~d}$ (CIDR3) before the onset of the Cosynch program.

${ }^{3}$ Progesterone.

${ }^{4}$ Estradiol-173.

${ }^{5}$ Cyclicity was based on serum progesterone concentrations 28, 14, and $0 \mathrm{~d}$ before the onset of a timed AI program.

${ }^{6}$ Average of the largest 2 of the first 3 test-day milk weights after calving.

success. Cows with at least 1 CL were 4.1 times more $(P=0.007 ; 95 \% \mathrm{CI}=1.47$ to 11.3$)$ likely to ovulate than cows with no CL at $\mathrm{PGF}_{2 \alpha}$. Further, cows with progesterone concentrations $<1 \mathrm{ng} / \mathrm{mL}$ were 3.6 times more $(P=0.002 ; 95 \% \mathrm{CI}=1.65$ to 7.81$)$ likely to ovulate than cows with progesterone $\geq 1 \mathrm{ng} / \mathrm{mL}$ before GnRH-2.

\section{Progesterone and Post-Al Fertility}

Progesterone concentrations at $4 \mathrm{~d}$ after TAI were greater $(P<0.05)$ in CIDR3 cows than in cows in all other treatments, but this difference was no longer detectable by d 11 post TAI (Figure 2). The greater progesterone concentration in CIDR3 cows on d 4 was related to failure of the CL to regress in 8 of 47 cows. Although PR/AI in CIDR3 cows was consistently 50\% of that in cows in other treatments at $\mathrm{d} 32$ and 60 postTAI (Figure 3), none of the presynchronization treatments improved PR/AI compared with the Cosynch control.

\section{Correlations Between CL Traits and Progesterone}

Simple correlations between the number of CL and progesterone concentrations at GnRH-1 $(\mathrm{r}=0.53 ; P<$ $0.001 ; \mathrm{n}=302)$ were similar to those between total CL volume and progesterone concentrations at GnRH-1 ( $\mathrm{r}$ 


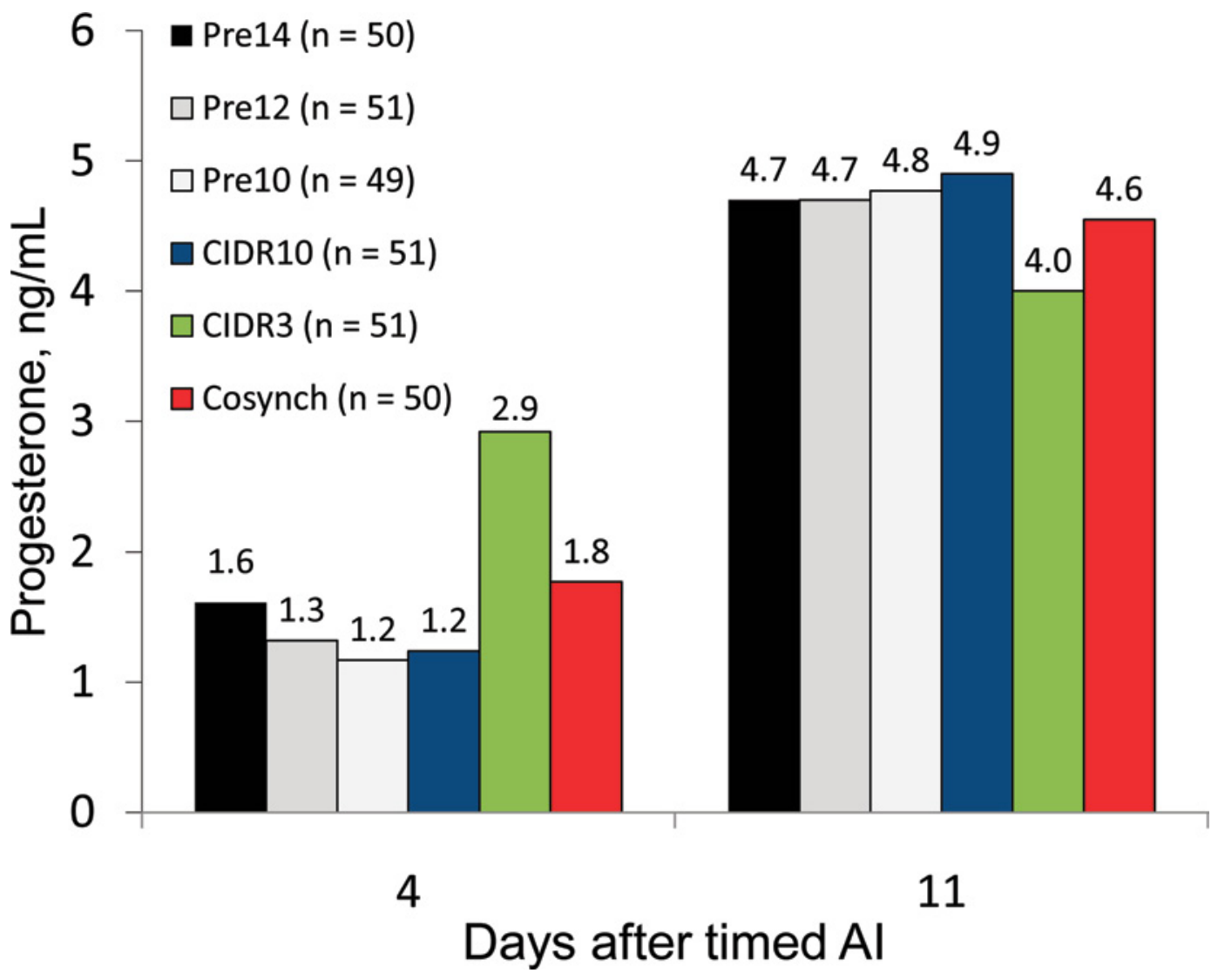

Figure 2. Serum progesterone concentrations 4 and $11 \mathrm{~d}$ after timed AI for lactating dairy cows treated with the Pre14, Pre12, Pre10, CIDR10, CIDR3, or Cosynch treatments. Injections of $\mathrm{PGF}_{2 \alpha}$ were administered $14 \mathrm{~d}$ apart, with the second injection administered $14 \mathrm{~d}$ (Pre14), $12 \mathrm{~d}$ (Pre12), or $10 \mathrm{~d}$ (Pre10) before the onset of the Cosynch program (see Figure 1). A progesterone-releasing controlled internal drug release (CIDR) insert was inserted for $7 \mathrm{~d}$ and removed either $10 \mathrm{~d}$ (CIDR10) or $3 \mathrm{~d}$ (CIDR3; negative control) before the onset of the Cosynch program. On d 4, mean progesterone concentrations $(\mathrm{SEM}=0.24)$ differed $(P<0.001)$ between CIDR3 and all other treatments, but no differences $($ SEM $=0.38)$ among treatments were detected on $\mathrm{d} 8$. Color version available in the online PDF.

$=0.57 ; P<0.001 ; \mathrm{n}=212)$. In contrast, magnitude of the correlation between the number of CL and total CL volume was less $(\mathrm{r}=0.33 ; P<0.001 ; \mathrm{n}=212)$. Similar correlations were calculated for these traits at the time of the $\mathrm{PGF}_{2 \alpha}$ injection. The correlation between the number of $\mathrm{CL}$ and progesterone concentrations $(\mathrm{r}=$ $0.53 ; P<0.001 ; \mathrm{n}=302)$ was similar to that between total CL volume and progesterone concentrations ( $\mathrm{r}$ $=0.51 ; P<0.001 ; \mathrm{n}=274)$. Again, the correlation between the number of CL and total CL volume was of lesser magnitude $(\mathrm{r}=0.42 ; P<0.001 ; \mathrm{n}=274)$, but numerically greater than that observed at GnRH-1.

\section{Effect of CIDR Treatment on Anovulatory Cows}

Pretreatment ovarian cyclicity ranged from 69 to $84 \%$ before treatments were applied (based on progesterone concentrations on $\mathrm{d}-28$ and -14 ; Figure 4). After treatments were applied, the proportion of cows with at least 1 sample of elevated progesterone $(\geq 1 \mathrm{ng} / \mathrm{mL})$ on $\mathrm{d}-28,-14$, and 0 ranged from 80 to $93 \%$ and did not differ at the onset of the Cosynch program (d 0).

Of 34 anovulatory cows [reduced progesterone $(<1$ $\mathrm{ng} / \mathrm{mL}$ ) on $\mathrm{d}-28,-14$, and 0 and no visible CL at GnRH-1] treated with a CIDR or no CIDR, a few responses were ameliorated by progesterone treatment (Table 5). Ovulatory response to GnRH-2 was greater $(P=0.019)$ in cows previously treated with progesterone. Synchronization rate was improved $(P=0.019)$ by CIDR treatment, and progesterone concentration $11 \mathrm{~d}$ after TAI tended $(P=0.075)$ to be greater than that in anovulatory cows not treated with progesterone. For a limited number of cows, PR/AI at d $32(P=0.075)$ and d $60(P=0.082)$ tended to be greater in cows previously treated with a CIDR insert.

\section{DISCUSSION}

The study objective was to test 5 potential presynchronization programs administered before a TAI 


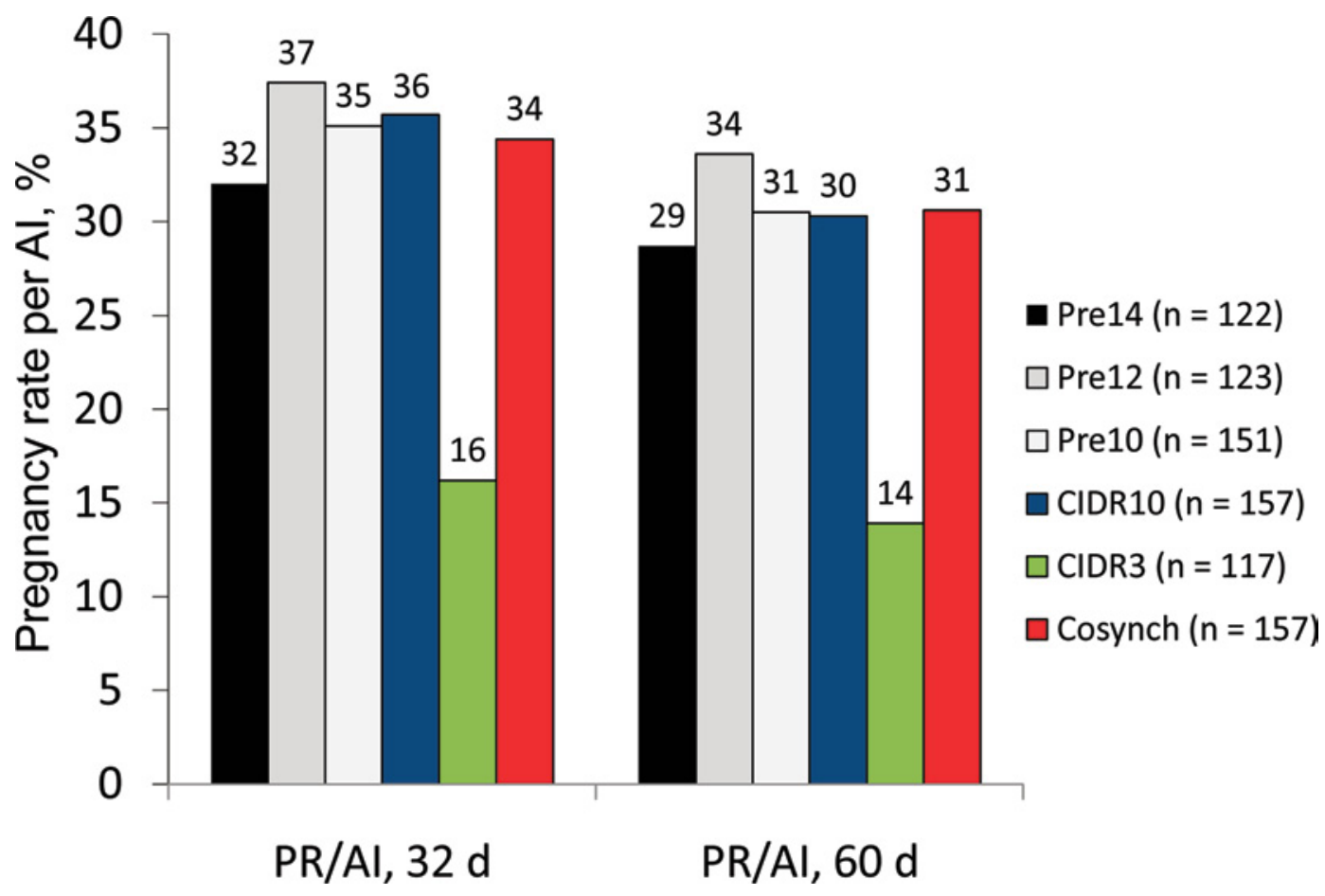

Figure 3. Pregnancy rates (PR) per AI at 32 and $60 \mathrm{~d}$ after timed AI for cows treated with the Pre14, Pre12, Pre10, CIDR10, CIDR3, or Cosynch treatments. Injections of $\mathrm{PGF}_{2 \alpha}$ were administered $14 \mathrm{~d}$ apart, with the second injection administered $14 \mathrm{~d}$ (Pre14), $12 \mathrm{~d}$ (Pre12), or 10 $\mathrm{d}$ (Pre10) before the onset of the Cosynch program (see Figure 1). A progesterone-releasing controlled internal drug release (CIDR) insert was inserted for $7 \mathrm{~d}$ and removed either $10 \mathrm{~d}$ (CIDR10) or $3 \mathrm{~d}$ (CIDR3; negative control) before the onset of the Cosynch program. On d 32 and 60 after timed AI, PR/AI in the CIDR3 treatment differed $(P<0.01)$ from that in all other treatments. Color version available in the online PDF.

program that might improve the percentage of cows with characteristics known to improve subsequent PR/ AI. Improved ovulation response to GnRH-1 (Bello et al., 2006; Stevenson et al., 2007) and GnRH-2 (Galvão and Santos, 2010) should result in greater PR/AI. To that end, multiple characteristics were examined in more than 300 cows to which 5 treatments were applied. On the basis of previous literature in which clear differences in PR/AI were observed (El-Zarkouny et al., 2004; Navanukraw et al., 2004; Galvão et al., 2007), it was anticipated that differences would be detected in ovarian characteristics for cows to which presynchronization treatments (Pre14, Pre12, and Pre10) were applied before Cosynch. Examination of progesterone concentrations revealed that in cows with at least 1 CL, CL volume, diameter of the largest follicle, and ovulation occurrence in response to GnRH-1 were not affected by treatment. Further, PR/AI was similar among treatments, and no trend toward expected differences was detected for cows treated with common Presynch treatments (e.g., Pre14 or Pre12) as reported earlier (El-Zarkouny et al., 2004; Navanukraw et al., 2004; Galvão et al., 2007).

Galvão and Santos (2010) recently reported that presynchronization with 2 injections of $\mathrm{PGF}_{2 \alpha}$ and

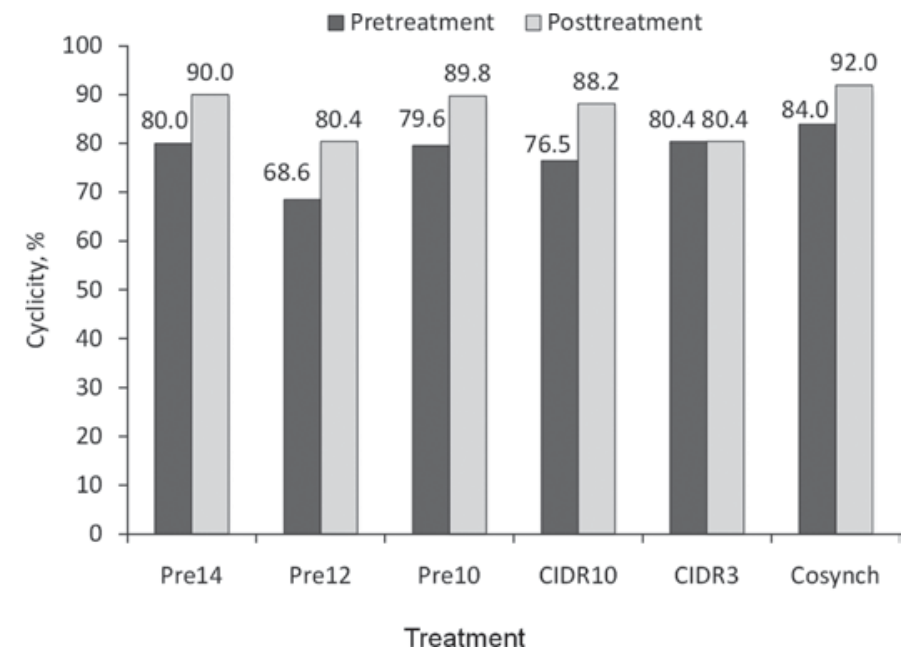

Figure 4. Pretreatment cyclicity was based on serum progesterone concentrations 28 and $14 \mathrm{~d}$ before the onset of a timed AI program (Cosynch). Posttreatment cyclicity was based on serum progesterone concentrations 28,14 , and $0 \mathrm{~d}$ before the onset of a timed AI program. Injections of $\mathrm{PGF}_{2 \alpha}$ were administered $14 \mathrm{~d}$ apart, with the second injection administered $14 \mathrm{~d}$ (Pre14), $12 \mathrm{~d}$ (Pre12), or $10 \mathrm{~d}$ (Pre10) before the onset of the Cosynch program (see Figure 1). A progesteronereleasing controlled internal drug release (CIDR) insert was inserted for $7 \mathrm{~d}$ and removed either $10 \mathrm{~d}$ (CIDR10) or $3 \mathrm{~d}$ (CIDR3; negative control) before the onset of the Cosynch program. 
Table 5. Responses assessed during the Cosynch program in anovulatory cows previously treated with progesterone $(\mathrm{P} 4)^{1}$

\begin{tabular}{|c|c|c|c|c|c|}
\hline \multirow[b]{2}{*}{ Item } & \multicolumn{3}{|c|}{ Progesterone treatment $^{2}$} & \multirow[b]{2}{*}{$\begin{array}{l}\text { No } \\
\text { CIDR }\end{array}$} & \multirow[b]{2}{*}{$P$-value ${ }^{3}$} \\
\hline & CIDR10 & CIDR3 & $\begin{array}{l}\text { CIDR } \\
\text { total }\end{array}$ & & \\
\hline Cows, $\mathrm{n}$ & 5 & 9 & 14 & 20 & \\
\hline \multicolumn{6}{|l|}{ GnRH-1 ${ }^{4}$} \\
\hline Ovulation, $\%$ & $40.0(2 / 5)$ & $33.3(3 / 9)$ & $35.7(5 / 14)$ & $50.0(10 / 20)$ & 0.416 \\
\hline $\mathrm{P} 4, \mathrm{ng} / \mathrm{mL}$ & $0.3 \pm 0.09$ & $0.3 \pm 0.06$ & $0.32 \pm 0.05$ & $0.3 \pm 0.07$ & 0.937 \\
\hline $\begin{array}{l}\mathrm{P} 4 \text { at } \mathrm{PGF}_{2 \alpha}, \mathrm{ng} / \mathrm{mL} \\
\mathrm{GnRH}^{4} 2^{4}\end{array}$ & \multicolumn{4}{|c|}{ GnRH-2 $2^{4}$} & 0.142 \\
\hline Ovulation, $\%$ & $80.0(4 / 5)$ & $100(9 / 9)$ & $92.9(13 / 14)$ & $55.0(11 / 20)$ & 0.019 \\
\hline Progesterone, ng/mL & $0.3 \pm 0.1$ & $0.5 \pm 0.09$ & $0.48 \pm 0.07$ & $0.3 \pm 0.06$ & 0.138 \\
\hline Luteolysis, ${ }^{5} \%$ & $100(3 / 3)$ & $85.7(6 / 7)$ & $90.0(9 / 10)$ & $100(12 / 12)$ & 0.273 \\
\hline $\begin{array}{l}\text { Synchronization rate }{ }^{6} \% \\
\mathrm{P} 4, \mathrm{ng} / \mathrm{mL}\end{array}$ & $80.0(4 / 5)$ & $100(9 / 9)$ & $92.9(13 / 14)$ & $55.0(11 / 20)$ & 0.019 \\
\hline $4 \mathrm{~d}$ post-TAI & $1.4 \pm 0.5$ & $1.6 \pm 0.4$ & $1.5 \pm 0.4$ & $0.8 \pm 0.4$ & 0.123 \\
\hline $11 \mathrm{~d}$ post-TAI & $4.5 \pm 0.9$ & $3.1 \pm 0.4$ & $3.6 \pm 0.4$ & $2.3 \pm 0.4$ & 0.075 \\
\hline \multicolumn{6}{|l|}{ PR/AI, \% } \\
\hline d 32 & $0(0 / 5)$ & $25.0(2 / 8)^{7}$ & $15.4(2 / 13)$ & $0(0 / 20)$ & 0.075 \\
\hline d 60 & $0(0 / 5)$ & $25.0(2 / 8)$ & $15.4(2 / 13)$ & $0(0 / 19)$ & 0.082 \\
\hline
\end{tabular}

${ }^{1}$ Cows having no corpus luteum on d 0 and low progesterone concentrations $(<1 \mathrm{ng} / \mathrm{mL})$ on $\mathrm{d}-28,-14$, and 0 from the onset of the Cosynch program.

${ }^{2}$ Treatment with a progesterone-releasing controlled internal drug release (CIDR) insert for $7 \mathrm{~d}$ and removed either 10 or $3 \mathrm{~d}$ before the onset of the Cosynch program.

${ }^{3}$ Comparisons between no CIDR and CIDR total.

${ }^{4}$ First (GnRH-1) or second (GnRH-2) injections of GnRH during the Cosynch program.

${ }^{5}$ Proportion of cows having luteal regression (decrease in progesterone concentrations from $\geq 1 \mathrm{ng} / \mathrm{mL}$ before $\mathrm{PGF}_{2 \alpha}$ to $<1 \mathrm{ng} / \mathrm{mL} 48 \mathrm{~h}$ later).

${ }^{6}$ Synchronization rate (proportion of cows having luteolysis and ovulating after GnRH-2).

${ }^{7}$ One cow was culled before pregnancy diagnosis on d 32 .

initiation of Ovsynch $14 \mathrm{~d}$ later decreased ovulatory responses of dairy cows to both injections of $\mathrm{GnRH}$ compared with a standard Ovsynch control, which suggests the 14-d interval between presynchronization and GnRH-1 is not adequate to predispose better fertility in dairy cows. The same group (Galvão et al., 2007) reported improved PR/AI for cows treated with a Pre11 compared with a Pre14 presynchronization scheme. In that study, improvement in PR/AI between Pre11 and Pre14 treatments was associated with increased ovulation to GnRH-1 for Pre11 cows. When comparing Pre14 and Pre10 treatments, a similar trend was observed for an increase in PR/AI for Pre10 cows (Figure $3)$. This trend was consistent with our anticipation that a greater ovulatory response to GnRH-1 would occur in Pre10 cows because more first-wave follicles were likely present at the onset of Cosynch (calculated cycle d 5 to 10) than in Pre14 (calculated cycle d 9 to 13) cows. Ovulatory responses to GnRH-1 in Pre14, Pre12, and Pre10 cows in the present study were in the $60 \%$ range and agreed with those reported by Galvão et al. (2007) for Pre11 cows. But in that study, ovulatory response for Pre14 cows was only $45 \%$ and produced a significant difference in ovulation response to GnRH-1 between Pre11 and Pre14 cows.
It was observed that cows with elevated progesterone and follicles $>14 \mathrm{~mm}$ at GnRH-1 had greater incidences of ovulation after GnRH-1 and that cows with at least $1 \mathrm{CL}$ at the time of $\mathrm{PGF}_{2 \alpha}$ and low progesterone at GnRH-2 also had greater ovulation after GnRH-2. These findings are consistent with suggested mechanisms by which stage of estrous cycle or follicular maturation predispose improve fertility resulting from a TAI program. Improved PR/AI in TAI programs is associated with (1) greater ovulation response to the first $\mathrm{GnRH}$ injection of Ovsynch (Vasconcelos et al., 1999; Bello et al., 2006), (2) more cows having a functional CL at the first GnRH injection (Galvão and Santos, 2010), (3) greater ovulatory response to the first $\mathrm{GnRH}$ injection increasing ovulatory response to the second GnRH injection (Rutigliano et al., 2008), and (4) greater ovulation response after TAI (Galvão and Santos, 2010).

In the present study, responses measured for the CIDR10 treatment were similar to those for the other standard Presynch treatments. Four other studies have incorporated a CIDR into a standard Pre14 Presynch program, with $11 \mathrm{~d}$ (Bruno et al., 2009), $12 \mathrm{~d}$ (Cerri et al., 2009), 13 d (Chebel et al., 2006), or 14 d (Bicalho et al., 2007) between CIDR insert removal and $\mathrm{PGF}_{2 \alpha}$ injection and the onset of a TAI program. Fertility was 
not improved in any of these studies, but ovulation response to GnRH-1 was increased in one study (Bruno et al., 2009). Further, the treatment with a CIDR insert reduced the ovulation response to GnRH-1 compared with a Pre13 Presynch program. One study (Rutigliano et al. 2008) duplicated the CIDR3 treatment, but no decrease was detected in PR/AI in this treatment when compared with a Pre12 treatment in that study. Because of its lack of profertility effects on PR/AI, it seems that applying a CIDR insert as a presynchronization tool before TAI is not warranted.

In contrast, the CIDR may have indirect effects on fertility because of progesterone's ability to induce estrous cycles. A greater proportion of anestrous cows receiving a CIDR insert during the last $7 \mathrm{~d}$ between $\mathrm{PGF}_{2 \alpha}$ injections in a Pre13 treatment became cyclic by d 62 compared with cows that did not receive CIDR insert (Chebel et al., 2006). Further, a new or used autoclaved CIDR incorporated into a Pre12 treatment resulted in more induced estrous cycles and prevented shortened estrous cycles after AI (Cerri et al., 2009). Results of the present study support the concept that use of progesterone during a presynchronization treatment induces estrous cycles in anovulatory cows. In the present study, more cows, albeit in limited numbers, receiving a CIDR insert ovulated in response to GnRH2 and had a greater progesterone concentration after AI compared with cows that did not receive a CIDR. Although fertility was not improved in other studies with a presynchronizing CIDR treatment (Chebel et al., 2006, Bicalho et al., 2007; Bruno et al., 2009; Cerri et al., 2009), fertility was increased in cycling vs. anovulatory cows. Nonetheless, no anovulatory cows in the present study conceived after the TAI except those that received a CIDR insert.

Progesterone concentrations before GnRH-1 and $\mathrm{PGF}_{2 \alpha}$ were equally correlated $(\mathrm{r}>0.5)$ with the total volume of luteal tissue, indicating that measures of luteal volume and luteal production of progesterone are well correlated. Positive correlations of progesterone concentration with ultrasound-derived luteal area were reported previously (Kastelic et al., 1990), but were of slightly greater magnitude $(\mathrm{r}=0.72$ to 0.76$)$ than those in the present study.

\section{CONCLUSIONS}

Results of the present study fail to support the findings that absence of $\mathrm{CL}$ at $\mathrm{GnRH}-1$ increased rate of single ovulations (Galvão and Santos, 2010). This may be partly explained by the large incidence $(70.5 \%)$ of cows in the present study having a CL at GnRH-1. Cows in the present study with larger follicles and elevated progesterone were more likely to ovulate after GnRH-1, whereas cows with at least $1 \mathrm{CL}$ at $\mathrm{PGF}_{2 \alpha}$ and baseline progesterone before GnRH-2 had the best ovulation responses after GnRH-2. These results support the conclusion (Galvão and Santos, 2010) that strategies to increase the proportion of cows with a CL or high progesterone at GnRH-1 should be sought. Ovulation after GnRH-2, however, is much more critical to pregnancy outcome than the success of ovulation to GnRH-1. Under conditions of this 1-herd long-term study, no trends in PR/AI were noted except for the negative effect of applying progesterone for $7 \mathrm{~d}$ and removing the CIDR $3 \mathrm{~d}$ before initiating the TAI protocol.

\section{ACKNOWLEDGMENTS}

I gratefully acknowledge former graduate students from Kansas State University, Manhattan, who assisted with blood collection and ovarian sonograms as part of this 5-yr study (D. E. Tenhouse, M. A. Portaluppi, C. A. Blevins, B. S. Buttrey, and M. G. Burns). I thank I. Vanderwerff and J. W. Gardner for performing the radioimmunoassays for progesterone and C. Hill for performing the radioimmunoassays of estradiol. Donations of CIDR inserts and Lutalyse by Pfizer Animal Health; Cystorelin by Merial Ltd., and OvaCyst by IVX Animal Health are gratefully acknowledged. Partial funding for this study was provided by Select Sires, Inc. (Plain City, OH).

\section{REFERENCES}

Bello, N. M., J. P. Steibel, and J. R. Pursley. 2006. Optimizing ovulation to first $\mathrm{GnRH}$ improved outcomes to each hormonal injection of Ovsynch in lactating dairy cows. J. Dairy Sci. 89:3413-3424.

Bicalho, R. C., S. H. Cheong, L. D. Warnick, and C. L. Guard. 2007. Evaluation of progesterone supplementation in a prostaglandin $\mathrm{F}_{2 \alpha}$-based presynchronization protocol before timed insemination. J. Dairy Sci. 90:1193-1200.

Bruno, R. G. S., A. C. Denicol, D. F. Resende, G. Lopes Jr., L. G. D. Mendonca, F. A. Rivera, J. E. P. Santos, and R. C. Chebel. 2009. Effect of progesterone insert during presynchronization program on reproductive responses of dairy cows. J. Dairy Sci. 92(Suppl. 1):263.(Abstr.)

Cartmill, J. A., S. Z. El-Zarkouny, B. A. Hensley, G. C. Lamb, and J. S. Stevenson. 2001. Stage of cycle, incidence and timing of ovulation, and pregnancy rates in dairy cattle after three timed breeding protocols. J. Dairy Sci. 84:1051-1059.

Cerri, R. L. A., H. M. Rutigliano, R. G. S. Bruno, and J. E. P. Santos. 2009. Progesterone concentrations, follicular development and induction of cyclicity in dairy cows receiving intravaginal progesterone inserts. Anim. Reprod. Sci. 110:56-70.

Chebel, R. C., J. E. P. Santos, R. L. A. Cerri, H. M. Rutigliano, and R. G. S. Bruno. 2006. Reproduction in dairy cows following progesterone insert presynchronization and resynchronization protocols. J. Dairy Sci. 89:4205-4219.

El-Zarkouny, S. Z., J. A. Cartmill, B. A. Hensley, and J. S. Stevenson. 2004. Pregnancy in dairy cows after synchronized ovulation regimens with or without presynchronization and progesterone. J. Dairy Sci. 87:1024-1037.

Ferguson, J. D., D. T. Galligan, and N. Thomsen. 1994. Principal descriptors of body condition score in Holstein cows. J. Dairy Sci. $77: 2695-2703$. 
Galvão, K. N., M. F. Sá Filho, and J. E. P. Santos. 2007. Reducing the interval from presynchronization to initiation of timed artificial insemination improves fertility in dairy cows. J. Dairy Sci. 90:4212-4218

Galvão, K. N., and J. E. P. Santos. 2010. Factors affecting synchronization and conception rate after the Ovsynch protocol in lactating Holstein cows. Reprod. Domest. Anim. 45:439-446.

Kastelic, J. P., D. R. Burgess, and O. J. Ginther. 1990. Relationship between ultrasonic assessment of the corpus luteum and plasma progesterone concentration in heifers. Theriogenology 33:12691277.

LeBlanc, S. J., and K. E. Leslie. 2003. Presynchronization using a single injection of $\mathrm{PGF}_{2 \alpha}$ before synchronized ovulation and first timed artificial insemination in dairy cows. J. Dairy Sci. 86:32153217.

Meyer, J. P., R. P. Radcliff, M. L. Rhoads, J. F. Bader, C. N. Murphy, and M. C. Lucy. 2007. Timed artificial insemination of two consecutive services in dairy cows using prostaglandin $\mathrm{F}_{2 \alpha}$ and gonadotropin-releasing hormone. J. Dairy Sci. 90:691-698.

Moreira, F., R. L. de la Sota, T. Diaz, and W. W. Thatcher. 2000. Effect of day of the estrous cycle at the initiation of a timed artificial insemination protocol on reproductive responses in dairy heifers. J. Anim. Sci. 78:1568-1576.

Moreira, F., C. Orlandi, C. A. Risco, R. Mattos, F. Lopes, and W. W. Thatcher. 2001. Effects of presynchronization and bovine somatotropin on pregnancy rates to a timed artificial insemination protocol in lactating dairy cows. J. Dairy Sci. 84:1646-1659.

NRC. 2001. Nutrient Requirements of Dairy Cattle. 7th rev. ed. Natl. Acad. Sci., Washington, DC.

Navanukraw, C., D. A. Redmer, L. P. Reynolds, J. D. Kirsch, A. T. Grazul-Bilska, and P. M. Fricke. 2004. A modified presynchronization protocol improves fertility to timed artificial insemination in lactating dairy cows. J. Dairy Sci. 87:1551-1557.
Perry, R. C., L. R. Corah, G. H. Kiracofe, J. S. Stevenson, and W. E. Beal. 1991. Endocrine changes and ultrasonography of ovaries in suckled beef cows during resumption of postpartum estrous cycles. J. Anim. Sci. 69:2548-2555.

Rutigliano, H. M., F. S. Lima, R. L. A. Cerri, L. F. Greco, J. M. Vilela, V. Magalhães, F. T. Silvestre, W. W. Thatcher, and J. E. P. Santos. 2008. Effects of method of presynchronization and source of selenium on uterine health and reproduction in dairy cows. J. Dairy Sci. 91:3323-3336.

Skaggs, C. L., B. V. Able, and J. S. Stevenson. 1986. Pulsatile or continuous infusion of luteinizing hormone-releasing hormone and hormonal concentrations in prepubertal beef heifers. J. Anim. Sci. 62:1034-1048.

Souza, A. H., H. Ayres, R. M. Fereira, and M. C. Wiltbank. 2008. A new presynchronization system (double-Ovsynch) increases fertility at first postpartum timed AI in lactating dairy cows. Theriogenology 70:208-215.

Stevenson, J. S., M. A. Portaluppi, and D. E. Tenhouse. 2007. Factors influencing upfront single and multiple-ovulation incidence, progesterone, and luteolysis before a timed insemination resynchronization protocol. J. Dairy Sci. 90:5542-5551.

Stevenson, J. S., J. R. Pursley, H. A. Garverick, P. M. Fricke, D. J. Kesler, J. S. Ottobre, and M. C. Wiltbank. 2006. Treatment of cycling and noncycling lactating dairy cows with progesterone during Ovsynch. J. Dairy Sci. 89:2567-2578.

Vasconcelos, J. L. M., R. W. Silcox, G. J. Rosa, J. R. Pursley, and M. C. Wiltbank. 1999. Synchronization rate, size of the ovulatory follicle, and pregnancy rate after synchronization of ovulation beginning on different days of the estrous cycle in lactating dairy cows. Theriogenology 52:1067-1078. 